\title{
Factors Influencing Auditor Independence among Listed Companies in Nigeria: Generalized Method of Moments (GMM) Approach
}

\author{
Mary Kehinde Salawu ${ }^{1}$ \\ ${ }^{1}$ Department of Management and Accounting, Obafemi Awolowo University, Ile-Ife, Nigeria \\ Correspondence: Mary Kehinde Salawu, Department of Management and Accounting, Obafemi Awolowo \\ University, Ile-Ife, Nigeria. E-mail: marysalawu@yahoo.com, rsalawu@ oauife.edu.ng
}

Received: April 5, 2017

doi:10.5539/ijef.v9n8p191
Accepted: June 23, 2017

Online Published: July 20, 2017

\begin{abstract}
The study examines the factors influencing auditor independence among listed companies in Nigeria. A sample of 65 firms out of the 194 listed on the Nigerian Stock Exchange (NSE) were purposively selected for analysis, these comprise 14 money deposit banks (financial), 1 mortgage bank and 50 non-financial firms. Secondary data were employed for the study and were sourced from the audited financial reports of sampled companies and fact book of the Nigerian Stock Exchange between the periods of 2006 and 2013. Data were analysed using descriptive statistics and Generalised Method of Moments (GMM). Preliminary tests were carried out such as Sargan test, Arellano-Bond Serial Correlation Test among others. The study revealed that Big4, audit tenure, profitability, leverage and inventory with account receivable had negative significant impact, which can impair auditor independence, while size of the firms and loss had positive influence on auditor independence in Nigeria. Also, the square root of the number of subsidiaries was positively related to auditor independence, but not significant and the total number of subsidiaries had positive influence on auditor independence but not significant. These results implied that the two variables can increase the complexity of the audit and, consequently, a rise in audit fees expect in their presence. This will in turn reduce auditor independence. The study therefore recommended that joint audit be adopted and audited tenure be reviewed. The findings of the study would enable management, regulators, investors and other stock market participants to play their unique and important roles in enhancing auditor independence in Nigeria.
\end{abstract}

Keywords: audit fee, auditor independence, Nigeria, audit tenure

\section{Introduction}

The incidence of financial crisis witnessed by many nations particularly developing economies and the attendant loss of confidence by economic actors, has raised many questions about the expected roles of auditors in corporate financial reporting. For instance, the cry of the investing public had invariably been "Where were the Auditors?" (Akinjobi \& Omowumi, 2010).

The major role of external auditors is to express an opinion on whether or not an entity's financial statements show a true and fair view and are free of material misstatements. Gallegos (2004) attested to the fact that the report of the independent auditor provides key assurance to investors. The monitoring role of the auditors therefore promotes the reliance and trust of users of financial statements.

As response to the devastating collapse of major corporations, the Sarbanes-Oxley Act (SOX) was passed in the United States of America with the purpose of upgrading the audit process. The SOX, for instance, prohibits the offering of non-audit services to audit clients and requires rotation of the lead auditor or coordination partner and the reviewing partner every five years to avoid becoming close to management at a personal level and dependent on the company and the audit fees for advancement within the firm.

As a further measure to ensure the credibility of accounting information and the reliability of financial statements, emphasis is also placed on the independence of the auditor. Auditor independence is a state of being free by the external auditor from any form of undue pressure of management tacticsa aimed at influencing auditors to err form professional standards. Independence is seen to be pivotal to auditing right from the inception of the profession as it determines the quality as well as contributes to the reliance of accounting information users (Mautz \& Sharaf, 1961). Auditor independence helps to ensure quality audits and it contributes 
to the reliance of financial statement users on the financial reporting process (Lindberg \& Beck, 2004). However, as a result of pervasive, global audit disasters, several rhetoric questions about the existence of auditor independence are being asked by companies' stakeholders, especially in the face of dwindling quality of earnings.

Despite the importance and centrality of independence to audiot profession, auditors of today seek to expand their profit while at the same time strive for independence. These double prusuits pose a serious challenge to audit practices. It was reported that in 2000, the "Big Four" \{Deloitte Touche Tohmatsu (Akintola Williams Deloitte); KPMG; Ernst \& Young and PricewaterhouseCoopers \} earned 50\% of their income from management and consulting field which was only $13 \%$ in 1981 (SEC, 2000). The pursuit of profits however inhibits auditors from providing reasonable assurance that the financial statements as a whole are free from material misstatement (Mitchell \& Sikka, 2002).

As a result, audit profession suffers a dramatic turn down on the authenticity of audited reports as well as significance of the audit function. It is against this this backdrop that this study investigates the factors influencing auditor independence among listed companies in Nigeria using generalised Method of Moments. Apart from the above introductory section, the rest of this study has been divided into four sections. Section two discusses the literature review of the study. The third section focuses on the methodology adopted while the fourth section presented the results. The study is concluded in section five.

\section{Literature Review}

Prior studies asserted that high fees paid by a company to its external auditor increase the economic bond between the auditor and the client and thus, may impair the auditor's independence (Frankel et al., 2002; Li \& Lin, 2005). The impaired independence results in poor audit quality and allows for greater earnings management and lower earnings quality (Okolie, Izedonmi, \& Enofe 2013). An audit fee is applied to measure auditor independence (Palmrose, 1986, 1988; Moizer, 1997; Wooten, 2003; Craswell, Stokes, \& Laughton 2002; Amake \& Okafor, 2012; Okolie, 2014a). Hillison and Kennelley (1988) found that audit firms would charge lower audit fees to retain their clients and then charge higher fees on non-audit fees to recover the loss, thus impairing the auditor's independence.

It was found by Chan, Ezamel, and Gwilliam (1993); Pong and Whittington (1994) that companies' total revenue is a measure of audit fees among quoted companies in the United Kingdom. carried out a study on the determinants of audit fees for quoted companies in the United Kingdom and found that the total sales are relevant to measure audit fees. Similarly, Butterworth and Houghton (1995) investigated the pricing of audit service in Western Australia; the result of the regression model of the audit fees using the Ordinary Least Squares procedure found no statistically significant relationships between audit fees and non-audit fees in the Australian market. The findings of Craswell, Taylor, and Francis (1995) revealed that the size of a client's company, complexity and risk are the robust determinants of audit fees.

Low, Tan and Koh (1990) and Gerrard, Houghton, and Woodliff (1994) showed that the complexity of client's company influences the audit fees in that the auditors need longer time and more manpower to complete their audits. The empirical study of Ezzamel, Gwilliam, and Holland (1996) on the relationship between the pricing of audit and non-audit services found that the non-audit fees were positively and significantly related to the audit fees. These findings were also supported by Teoh and Lim (1996); Beattie and Fearnly (2003); Deakin and Konzelmann (2004); and Dart (2009).

Menon and William (2001) analysed long-term trends in audit fees from 1980 through 1997 with samples drawn from the voluntarily-disclosed audit fees data in SEC filings, especially the proxy statements. The study employed modified Simon and Francis (1988) model and adjusted for changes in client size, complexity, and risk in US companies. Coulton, Craswell, and Taylor (2001) in a study of 614 industrial companies listed on the ASX in 1998 found a positive association between the level of audit fees and the existence of an audit committee. This was also similar to the findings of Sharma (2003) on the top 500 quoted firms in Australia.

Craswell, Stokes, and Laughton (2002) studied the relationship between auditor independence and fee dependence. Auditor independence was measured as the propensity of auditors to issue a qualified audit opinion which was represented by the ratio of audit fee to total national fee of the audit firm. They used both univariate and multivariate logit regressions with the square root of the number of subsidiaries to represent complexity, the natural $\log$ of total client assets as a measure of size and the ratio of current assets to total assets as a measure of complexity. They also controlled for auditor type and industry. Essentially, they reported that the level of economic dependence between the auditor and their client does not affect auditor propensity to issue a qualified audit opinion. They argued that their result showed that in a setting where public disclosure of audit and 
non-audit fees is mandatory, auditors appear willing to issue qualified opinions irrespective of the economic importance of the client to the auditor.

Firth (2002) investigated auditor-provided consultancy services and their associations with audit fees and audit opinions as well as the associations with audit fees and audit opinions using a sample of 314 UK quoted companies and replicated his model in 1997. He found that there is positive association between consultancy fees and audit fees due to specific events like mergers and acquisitions, share issues, implementation of new accounting and information systems, appointment of new CEOs, and corporate restructures in the company that generate a demand for consultancy services as well as requiring additional audit effort. The result of the study showed a positive relationship between audit and non-audit fee in that an increase in the non-audit fee brought about a marginal increase in the audit fees.

Peel and Clatworthy (2001) showed that CEO duality does not influence external audit fees and, as supported by Mitra, Hossain, and Deis (2007), found that there is insignificant relationship with audit fees when the CEO also chair the board. Whisenant, Whisenant, Sankaraguruswamy, and Raghunandan (2003) used a simultaneous equation model and showed empirically that audit fees and non-audit fees are simultaneously determined. They found a positive relationship between audit fees and non-audit fees when $O L S$ is used, but they found no relationship when they use a simultaneous specification of the fee model applying two-stage least squares (2SLS).

Alam and Baez-Díaz (2005) found an association between audit and non-audit services using a simultaneous and single equation model and they pointed out that audit and non-audit fees are simultaneously determined in the banking industry in the U.S. This evidence is supported by Antle et al. (2006 Also, Hay, Knechel, and Li (2006) documented that in New Zealand, OLS regression results showed a positive association between audit and non-audit fees, but they found no relationship between audit and non-audit fees using a simultaneous-equation model applying 2SLS, suggesting that audit and non-audit services are jointly determined.

Hay, Knechel, and Ling (2008) in a study of over 130 companies on New Zealand Stock Exchange between the periods of 1995 and 2005, found that controls and stronger corporate governance is positively associated with demand for independent auditing services.

In the same vein, Adelopo and Jallow (2008) found through their study on board structures, audit committee characteristics and external auditors' fee behaviour that board independence was positively and significantly associated with audit and non-audit fees paid to the auditor. This invariably signals the board's competence and quality of audit. This was also similar the findings of Vafeas and Waegelein (2007).

Hamid and Abdullah (2011) examined the association between fees, and board and audit committee characteristics of 191 government-linked companies (GLCs) and non-government-linked companies (NGLCs) listed on the Bursa Malaysia between 2006 and 2008. The finding revealed that audit fees are positively and significantly related to the size of the board insignificantly related to other governance variables for GLCs and the board independence is positively and significantly associated with audit fees, while other governance variables present significant negative relationship with audit fees.

Oladipupo and Izedonmi (2011) investigated the relationship between auditor independence and the type of audit report issued. Data were sourced from the annual reports of 27 companies listed on the Nigerian Stock Exchange between 2002 and 2006. The results revealed that a positive relationship, though insignificant, exist between auditor independence and the nature of the audit reports issued by the auditors. It was found that audit fees have a direct link with the type of audit report auditors would issue. That is, the higher the audit fee, the lower the auditor independence and the higher the incidence of issuing unqualified audit reports.

In their study, Hamid and Ali (2012) extended previous work on audit fees by examining a data set derived from a 1997-2007 sample of Iran firms, which were publicly traded on the stock exchange of Iran. The principal purpose of their study was to investigate the association between the efficiency of audit fees base (audit quality, audit firm size, reputation and corporate brand, audit time budget and audit firm industry specialization) and audit fees. Using the level of audit fees as dependent variable for Iran firms, lagged audit fees were found to have the most significant coefficient of all variables included in the regression. The results of the study showed that audit report quality has a positive and significant effect on audit fees; therefore, quality is the most important effective factor in audit fees. Amake and Okafor (2012) empirically examined the relationship between auditor's tenure, audit firm size and auditor independence. The study used a sample of 50 Nigerian audit firms. The study employed binary logistic regression. The findings revealed that auditor tenure as well as audit firm size do not compromise the independence of the auditors. It was concluded that audit tenure might not exceed five years for auditor to maintain his independence. 
Enofe, Nbgame, Okunega, and Ediae (2013) investigated the relationship between audit quality and auditor independence using audited financial reports of 20 Nigerian companies listed on the Nigerian Stock Exchange for year 2011. The results of the ordinary least square (OLS) regression revealed that as auditors' independence increased, the quality of the audit also increased. However, as the independence of the board and the ownership structure increased, the quality of the audit reduced. The study concluded that the longer the audit tenure, the higher the quality of audits.

Furthermore, most of the previous studies adopted ordinary least square regression, non-parametric statistical tests, descriptive statistics etc (Chan, Ezamel, \& Gwilliam, 1993; Pong \& Whittington, 1994; Kleinman \& Palmon, 2001; Whisenant et al., 2003; Abu Bakar, Abdul Rahman, \& Abddul Rashid, 2005; Hay, Knechel, \& Li 2006; Oladele, 2008; Beattie, Brandt, \& Fearnley, 1999; Adeyemi \& Olowookere, 2012; Enofe, Nbgame, Okunega, \& Ediae, 2013). The current study used Generalised Method of Moments (GMM) for data analysis as a result of the dynamic nature of the models while at the same time corrected the deficiency of Ordinary Least Square method (OLS) employed by previous studies. Moreover, past studies in Nigeria focused majorly on non-financial firms while financial firms were excluded. The focus of this study is on both the non-financial and financial firms in Nigeria.

The theoretical framework for this study was anchored on agency theory. Agency theory aptly describes the relationships between the principal and his agent and how the role of contracts facilitates voluntary exchange between the parties. In the corporate world, an agency relationship exists between a firm's outside stockholders and its managers to the extent that stockholders delegate the day-to-day management of their investment to those managers. The most important basis of agency theory is that the managers are usually motivated by their own personal gains and work to exploit their own personal interests rather than considering shareholders' interests and maximising shareholders' value.

It is believed that agency problem results from information asymmetry that existed by virtue of the privileged information about the company's affair accessible by management (agent) only. This makes in literally difficult for the owners (principals) to control the actions of the management. Controversy occurs because principals are unable to monitor the performance of agents (Jensen \& Meckling, 1976; Eisenhardt, 1989).

Arnold and Lange (2004) argued that incentives and monitoring mechanisms are proposed as safeguards against opportunism in the agent/principal relationship. The theory recognises external auditing as the most important monitoring mechanism because it controls conflicts of interest and diminishes agency costs. An audit will be successful in changing expectations and hence reducing the opportunistic behaviour costs (agency costs) borne by the manager only if it is expected that the auditor will report some discovered breaches of contract.

\section{Data and Methodology}

Sample of 65 firms out of 194 listed on the Nigerian Stock Exchange (NSE) were purposively selected for analysis. These comprise 14 money deposit banks (financial), 1 mortgage bank and 50 non-financial firms. Furthermore, newly quoted companies were excluded from the study. Secondary panel data were employed for the study and were sourced from the audited financial reports of the sampled firms using purposive sampling technique. Data were analysed using generalised method of moments.

\subsection{Model Specification}

Simunic (1980a, 1980b) and DeAngelo (1981) provided other possibilities for examining auditor independence using economic modelling. This allowed independence in appearance to be captured by proxies such as ratio of audit to non-audit fees and the ratio of audit fee to total fees. Also, Palmrose (1986, 1988); Moizer (1997); Craswell, Stokes and Laughton (2002); Wooten (2003) as well as Okolie (2014a, 2014b) applied audit fee as a measure of auditor independence. In the current study, the natural log of audit fees as dependent variable, was used to measure auditor independence. This was in line with previous studies.

The study drew on Simunic (1980), Parkash and Venable (1993), Firth (1997), Whisenant et al. (2003), Cameran (2005) and De Fuentes (2005) to identify factors that influence auditor independence. Hence, the general model specification for auditor independence was stated in line with agency theory as follows:

$$
\begin{gathered}
A U D I N D_{i t}=\beta_{0}+\beta_{1} \text { Bsize }_{i t}+\beta_{2} \text { SIZE }_{i t}+\beta_{3} B_{I G F_{i t}}+\beta_{4} A U D T E N_{i t}+\beta_{5} L_{O S S}+\beta_{6} \text { OPINQUAL }_{i t}+\beta_{7} P_{R O F_{i t}}+ \\
\beta_{8} L E V_{i t}+\beta_{9} I N V R E C_{i t}+\beta_{I 0} S U B L O_{i t}+\beta_{I I} \text { SUBSFOR }_{i t}+\varepsilon_{t}
\end{gathered}
$$

However, as a result of the fact that the current year audit fee is heavily determined by the previous year audit fee and in order to avoid the predisposition of omitted variable, the lag of AUDIND was included in model 2 to give: 


$$
\begin{aligned}
& A_{U D I N D}=\beta_{0}+\beta_{1} A_{\text {UUDIND }} \text { it-1 }+\beta_{2} \text { Bsize }_{i t}+\beta_{3} \text { SIZE }_{i t}+\beta_{4} \text { BIGF }_{i t}+\beta_{5} \text { AUDTEN }_{i t}+\beta_{6} \text { LOSS }_{i t}+\beta_{7} \text { OPINQUAL }_{i t}+ \\
& \beta_{8} P_{R O F_{i t}}+\beta_{9} L E V_{i t}+\beta_{10} I N V R E C_{i t}+\beta_{1 I} S U B L O_{i t}+\beta_{12} S U B S F O R_{i t}+\varepsilon_{t}
\end{aligned}
$$

\begin{tabular}{|c|c|c|c|}
\hline Variables & Symbol & Measurement & $\begin{array}{c}\text { Apriori } \\
\text { Expectation }\end{array}$ \\
\hline Auditor Independence & AUDIND & Natural Logarithm of Audit fee & \\
\hline Lag of Auditor Independence & AUDIND $_{\text {it-1 }}$ & Natural log of the previous audit fee (in thousands of Naira) & \\
\hline Board Size & BSIZE & Total number of directors on the board & $+/-$ \\
\hline Size of the Firm & $\begin{array}{l}\text { SIZE } \\
\text { SIZE }\end{array}$ & $\begin{array}{l}\text { Natural log of total assets or turnover } \\
\text { Natural log of total sales }\end{array}$ & + \\
\hline Big Four Audit Firms & BIGF & $\begin{array}{l}\text { Variable equalled to } 1 \text { when the Auditor is a Big Four firm, and } 0 \text { if otherwise } \\
\text { (Akintola Williams Deloitte; KPMG; Ernst \& Young and } \\
\text { PricewaterhouseCoopers) }\end{array}$ & $+1-$ \\
\hline Audit Tenure & AUDTEN & Length of years in which auditor audit their client & $+/-$ \\
\hline Loss & LOSS & $\begin{array}{l}\text { Variable equalled to } 1 \text { if the firms report negative net income in the current } \\
\text { year or in the previous two years, and } 0 \text { if otherwise }\end{array}$ & - \\
\hline Qualified Opinion & $\begin{array}{l}\text { OPINQUA } \\
\text { L }\end{array}$ & $\begin{array}{l}\text { Variable equalled to } 1 \text { if the company received a qualified opinion in either the } \\
\text { current or previous year, and } 0 \text { if otherwise }\end{array}$ & - \\
\hline Profitability & PROF & Net Income less extraordinary items divided by total sales or turnover. & + \\
\hline Leverage & LEV & $\begin{array}{l}\text { Total Liabilities/Total Assets } \\
\text { Long term liabilities/Total Assets }\end{array}$ & - \\
\hline Inventory & INVREC & Inventory plus Accounts Receivable divided by total assets. & $+/-$ \\
\hline Local Subsidiaries & SUBLO & Number of local subsidiaries. & $+/-$ \\
\hline Foreign Subsidiaries & SUBSFOR & Number of foreign subsidiaries & $+/-$ \\
\hline
\end{tabular}

Table 1. Measurement of variables

Panel data technique was used to examine factors influencing auditor independence. Dynamic model was fitted to estimate the panel regression model. This was due to the incorporation of lag dependent variable on the right side of all the models (equation 1 and 2). Inclusion of lag dependent variable would introduce a risky amount of endongeneity in the model. Therefore, Arellano-Bond Generalised Methods of Moments (GMM) estimation technique was employed to correct this.

\section{Results and Discussion}

\subsection{Sargan Test and Arellano-Bond Serial Correlation Test}

The probability value of J-statistics of 0.782712 (value of the GMM objective function at estimated parameters) is insignificant. Therefore, the instruments are valid and the GMM estimates are reliable. Using the formular "Scalar pval = @ chisq (J-statistic, instrument rank - number of parameters estimated) gives the same probability value and this stands for sargan test of over-identifying restriction". The $p$-value was computed using Scalar Pval $=@$ chisq $(10.5659,27-12)$. The result gave the same value of p-value as reported for J-statistics. The results presented in Table 1 indicate the validity of the instruments used. Moreover, Arellano-Bond serial correlation test confirmed the efficiency of the first difference GMM estimator and the soundness of the results with AR (1) having p-value of 0.0033 (significant) and AR (2) having p-value of 0.6412 (not significant). There is no serial correlation in residual.

\subsection{Descriptive Analysis}

The mean value of auditor independence which is the dependent variable was 9.8998 with the standard deviation of 1.6094 which measured the extent to which the data series dispersed around the mean as indicated in Table 2. Skewness as a measure of asymmetry of the distribution of the series around the mean had a positive value of 0.0514 with the implication that auditor independence had a long right tail and hence most of the factors including the board size, size of the firm, opinion qualification, profitability, leverage, inventory with the receivables, local as well as the foreign subsidiaries, had long right tails and had influence on auditor independence. This was evident in average values of the afore-mentioned factors being greater than their median values. Additionally, Kurtosis as a measure of the peakness or flatness of the distribution of a series was 3.20 as against 3.0 (the standard for normally distributed data series), auditor independence was peaked (i.e. leptokurtic) relative to normal. The Jarque-Bera statistic of $1.1014(\mathrm{p}<0.01)$ suggested the normality of the distribution. 
Table 2. Descriptive statistics

\begin{tabular}{cccccccccccccc}
\hline Statistics/ & LAUDI & AUDIND & & & & & & & & & & & \\
Variables & ND & $\mathbf{( - 1 )}$ & BSIZE & SIZE & BIGF & AUDTEN & LOSS & OPINQUAL & PROF & LEV & INVREC & SUBLO & SUBSFOR \\
\hline Mean & 9.8997 & 9.8383 & 10.042 & 7.261 & 0.745 & 6.4874 & 0.2863 & 0.0116 & -8.0810 & 0.7385 & 25.0414 & 3.2321 & 1.1179 \\
Median & 9.7981 & 9.7351 & 9.0000 & 7.1216 & 1.0000 & 8.0000 & 0.0000 & 0.0000 & 0.0554 & 0.7128 & 0.3726 & 1.0000 & 0.0000 \\
Maximum & 15.2227 & 15.222 & 21.000 & 12.4157 & 1.0000 & 8.0000 & 1.0000 & 1.0000 & 237.68 & 8.8336 & 979.010 & 41.000 & 18.000 \\
Minimum & 4.4839 & 4.7246 & 4.0000 & 3.7845 & 0.0000 & 1.0000 & 0.0000 & 0.0000 & -1909.95 & 0.0008 & $3.85 \mathrm{E}-06$ & 0.0000 & 0.0000 \\
Std. Dev. & 1.6094 & 1.5884 & 3.3668 & 1.3018 & 0.4364 & 1.9733 & 0.4525 & 0.1072 & 112.478 & 0.4980 & 112.1764 & 5.7469 & 3.0594 \\
Skewness & 0.0514 & 0.0976 & 0.7783 & 1.0079 & -1.1222 & -1.0416 & 0.9457 & 9.1202 & -13.411 & 8.9315 & 5.2996 & 4.5657 & 3.9445 \\
KurtoSis & 3.2013 & 3.0752 & 3.3976 & 5.6772 & 2.2595 & 2.8569 & 1.8943 & 84.178 & 201.146 & 138.067 & 32.7731 & 29.357 & 19.1685 \\
Jarque-Bera & 1.1014 & 0.8247 & 55.6102 & 241.932 & 120.34 & 93.939 & 103.396 & 149125.4 & 861267.4 & 399861.3 & 21515.43 & 16761.34 & 6972.14 \\
Probability & 0.5765 & 0.6620 & 0.0000 & 0.0000 & 0.0000 & 0.0000 & 0.0000 & 0.0000 & 0.0000 & 0.0000 & 0.0000 & 0.0000 & 0.0000 \\
Sum & 5118.19 & 4446.941 & 5192.00 & 3753.85 & 385.00 & 3354.00 & 148.00 & 6.000 & -4177.886 & 381.842 & 12946.39 & 1671.0 & 578.00 \\
Sum Sq. Dev. & 1336.60 & 1137.955 & 5849.06 & 874.52 & 98.29 & 2009.17 & 105.63 & 5.9303 & 6528099. & 127.972 & 649311. & 17042.15 & 4829.80 \\
Observations & 452 & 452 & 452 & 452 & 452 & 452 & 452 & 452 & 452 & 452 & 452 & 452 & 452 \\
\hline
\end{tabular}

Source: Author's Computation 2015.

The mean value of the board size was 10.0426 with a standard deviation of 3.3668 which indicated that the average membership of the board of the sampled firms was 10 during the study period with a minimum of 4 and a maximum of 21 members. This indicated that membership of the Nigerian listed companies varied randomly with the size of companies. The mean response of firm size which was represented by the logarithm of total sale was 7.2608 with a standard deviation of 1.3018. This showed that there was much variation in the turnover (size) of the companies across the sample of the study. The mean values of the type of auditor, tenure of auditor, loss and opinion qualification were $0.7447,6.4874,0.2863$ and 0.0116 with standard deviation of $0.4364,1.9457$, 9.1202 and 0.1072 .

It was clear from the results that the big four audit firms audited about $74 \%$ of the companies listed on the Nigerian Stock Exchange leaving about $16 \%$ to other audit firms that operate in the country. Also, auditors were engaged on the average of 6 years which according to auditing standard on independence of auditor was normal. Average, profitability of -8.0810 which an indication that the firms' profitability ratio was low because the minimum value was -1909.95 and the maximum was 237.68 . Besides, there were great differences between the values of profitability ratio across companies as evident by very high standard deviation of 112.478.

The mean response score of leverage, inventory with receivables local subsidiaries and foreign subsidiaries were $0.7385,25.0414,3.2321$ and 1.1179 with standard deviation of $0.4980,112.1764,5.7469$ and 3.0594. Apart from the type of auditor and the auditor tenure, other variables were positively skewed. The values of kurtosis indicated that most of the variables, especially, opinion qualification, return on assets, leverage, inventory with account receivables, local as well as foreign subsidiaries were highly peaked. Audit tenure had approximately normal distribution while the shape of distribution for the type of auditor and loss were platy-kurtic. The Jarque-Bera (JB) test values of all the independent variables showed that their residual was not normally distributed since all their $\mathrm{p}$-values were significant at $1 \%$ level (i.e. $\mathrm{p}<0.01$ ).

\subsection{Multicollinearity Test}

Table 3 presented the correlation matrix among the independent variables included in the empirical specifications. The cut-off point of 0.5 is normally used for an indication of high correlation. Correlation analysis was run among variables and as it could be seen from the table, all the correlation coefficient among independent variables were less than 0.7 and also less than 0.5 with the exemption of only SUBLO and size which was 0.52. these results confirmed the assertion of Bryman and Cramer (1997) that the correlation between each pair of explanatory variables should not exceed 0.8. In addition to these, Loss, Opinion Qualification and Profitability were negatively correlated with most of the variables in the model. 
Table 3. Correlation analysis

\begin{tabular}{|c|c|c|c|c|c|c|c|c|c|c|c|c|}
\hline VARIABLES & LAUDIND(-1) & BSIZE & SIZE & BIGF & AUDTEN & LOSS & OPINQUAL & PROF & LEV & INVREC & SUBLO & SUBSFOR \\
\hline \multirow[t]{2}{*}{ LAUDIND(-1) } & 1.0000 & & & & & & & & & & & \\
\hline & ----- & & & & & & & & & & & \\
\hline \multirow[t]{2}{*}{ BSIZE } & 0.5730 & 1.0000 & & & & & & & & & & \\
\hline & 0.0000 & ---- & & & & & & & & & & \\
\hline \multirow[t]{2}{*}{ SIZE } & 0.5682 & 0.4309 & 1.0000 & & & & & & & & & \\
\hline & 0.0000 & 0.0000 & ----- & & & & & & & & & \\
\hline \multirow[t]{2}{*}{ BIGF } & 0.5582 & 0.3203 & 0.3329 & 1.0000 & & & & & & & & \\
\hline & 0.0000 & 0.0000 & 0.0000 & ----- & & & & & & & & \\
\hline \multirow[t]{2}{*}{ AUDTEN } & 0.0388 & -0.1836 & 0.0246 & 0.1315 & 1.0000 & & & & & & & \\
\hline & 0.4098 & 0.0001 & 0.6019 & 0.0051 & ----- & & & & & & & \\
\hline \multirow{2}{*}{ LOSS } & -0.0789 & -0.0659 & -0.1752 & -0.1463 & -0.0838 & 1.000000 & & & & & & \\
\hline & 0.0935 & 0.1613 & 0.0002 & 0.0018 & 0.0748 & ---- & & & & & & \\
\hline \multirow[t]{2}{*}{ OPINQUAL } & -0.0168 & -0.0037 & -0.0152 & 0.0152 & 0.0157 & 0.164672 & 1.000000 & & & & & \\
\hline & 0.7211 & 0.9367 & 0.7472 & 0.7473 & 0.7385 & 0.0004 & ----- & & & & & \\
\hline \multirow[t]{2}{*}{ PROF } & -0.0255 & -0.0757 & 0.0647 & -0.0339 & 0.0865 & -0.120089 & 0.007198 & 1.000000 & & & & \\
\hline & 0.5891 & 0.1079 & 0.1694 & 0.4715 & 0.0659 & 0.0106 & 0.8787 & ----- & & & & \\
\hline \multirow[t]{2}{*}{ LEV } & 0.1057 & 0.0198 & -0.0330 & 0.0666 & -0.0391 & 0.157792 & 0.113470 & -0.026256 & 1.000000 & & & \\
\hline & 0.0245 & 0.6740 & 0.4836 & 0.1570 & 0.4075 & 0.0008 & 0.0158 & 0.5777 & ----- & & & \\
\hline \multirow[t]{2}{*}{ INVREC } & 0.1059 & 0.2273 & -0.2715 & 0.0883 & -0.1993 & -0.005353 & -0.023289 & -0.192153 & 0.033470 & 1.000000 & & \\
\hline & 0.0243 & 0.0000 & 0.0000 & 0.0604 & 0.0000 & 0.9096 & 0.6214 & 0.0000 & 0.4778 & ----- & & \\
\hline \multirow[t]{2}{*}{ SUBLO } & 0.3038 & 0.2654 & 0.5274 & 0.1522 & 0.0181 & -0.017140 & -0.008036 & -0.113813 & 0.030203 & 0.101842 & 1.000000 & \\
\hline & 0.0000 & 0.0000 & 0.0000 & 0.0012 & 0.7010 & 0.7163 & 0.8647 & 0.0155 & 0.5219 & 0.0304 & ---- & \\
\hline \multirow[t]{2}{*}{ SUBSFOR } & 0.4243 & 0.4798 & 0.2529 & 0.1548 & -0.2228 & 0.027419 & -0.038723 & -0.039352 & 0.053932 & 0.188862 & 0.377432 & 1.000000 \\
\hline & 0.0000 & 0.0000 & 0.0000 & 0.0010 & 0.0000 & 0.5609 & 0.4115 & 0.4039 & 0.2525 & 0.0001 & 0.0000 & ----- \\
\hline
\end{tabular}

Source: Author's Computations, 2015.

Table 4. Unit root test results

\begin{tabular}{|c|c|c|c|}
\hline Variables & Levin, Lin \&Chu $t$ & ADF-Fisher Chi-sq & Status \\
\hline LAUDIND & $\begin{array}{c}-12.3147 * * * \\
(0.0000)\end{array}$ & $\begin{array}{c}194.948 * * * \\
(0.0001)\end{array}$ & $\mathrm{I}(0)$ \\
\hline BSIZE & $\begin{array}{c}-13.3657 * * * \\
(0.0000)\end{array}$ & $\begin{array}{c}140.032 * * * \\
(0.0107)\end{array}$ & $\mathrm{I}(0)$ \\
\hline SIZE & $\begin{array}{c}-16.0985^{* * *} \\
(0.0000)\end{array}$ & $\begin{array}{c}199.619 * * * \\
(0.0001)\end{array}$ & $\mathrm{I}(0)$ \\
\hline BIGF & $\begin{array}{c}-1.6186^{* *} \\
(0.0528)\end{array}$ & & $\mathrm{I}(0)$ \\
\hline AUDTEN & $\begin{array}{c}10.2121 * * * \\
(0.0000)\end{array}$ & & $\mathrm{I}(0)$ \\
\hline LOSS & $\begin{array}{c}-3.71839^{* * *} \\
(0.0001)\end{array}$ & & $\mathrm{I}(0)$ \\
\hline OPINQUAL & $\begin{array}{l}1.3908 * \\
(0.0822)\end{array}$ & & $\mathrm{I}(0)$ \\
\hline PROF & $\begin{array}{c}-34.6045^{* * *} \\
(0.0000)\end{array}$ & $\begin{array}{c}160.227 * * \\
(0.0370)\end{array}$ & $\mathrm{I}(0)$ \\
\hline LEV & $\begin{array}{c}-30.0853 * * * \\
(0.0000)\end{array}$ & $\begin{array}{c}217.677 * * * \\
(0.0000)\end{array}$ & $\mathrm{I}(0)$ \\
\hline INVREC & $\begin{array}{c}-33.8698 * * * \\
(0.0000)\end{array}$ & $\begin{array}{c}231.221^{* * *} \\
(0.0000)\end{array}$ & $\mathrm{I}(0)$ \\
\hline SUBLO & $\begin{array}{c}6.8303 * * * \\
(0.0000)\end{array}$ & & $\mathrm{I}(0)$ \\
\hline SUBSFOR & $\begin{array}{c}8.9968 * * * \\
(0.0000)\end{array}$ & & $\mathrm{I}(0)$ \\
\hline
\end{tabular}

Source: Author's Computation, 2015.

******* mean significant at $1 \%, 5 \%$ and $10 \%$ respectively. $\mathrm{P}$-values are in parenthesis. 


\subsection{Unit Root Test}

The dependent and the independent variables used in the regression analysis were separately subjected to panel unit root tests using Levin, Lin \& Chut, Im and ADF-Fisher Chi-square before estimating the model, in order to ensure the stationarity of the variables and that errors have zero mean and constant variance. It was clear from the panel unit root test table that all the variables were at levels as shown in Table 4.

\subsection{GMM Estimation of Factors Influencing Auditor Independence}

Table 5 presented the results of estimating the factors influencing auditor independence using the dynamic model. Large size of audit fees is normally associated with a higher risk of losing the auditor's independence. The IFAC's Code of Ethics for Professional Accountants (1996) suggests that client size (measured from size of fees) could raise doubts as to independence. The lagged dependent variable [LAUDIND (-1)] is insignificant and negative. This suggests that a current audit fees is negatively influenced by the auditor independence (log of audit fees) in the previous year, although the impact is not significant. It also implies that a $\$ 1$ increase in the previous audit fees will lead to a $\$ 0.09$ decrease in the current audit fee. This has positive implication on the auditor independence.

The result of board size (BSIZE) established an insignificant but positive relationship between the measure of board composition and audit fees paid to auditors. This result indicates that the higher the number of board size, the higher the total fees that are earned by the auditor from their client. The presence of more board members in the current Corporate Governance climate could encourage auditors to increase their audit work and coverage and also that such increase in audit efforts could be encouraged by the directors in an attempt to minimise the risk of future financial problems or frauds. This consequently leads to increased total fees accruing to the auditors for both auditing and non-auditing services. Increase in audit fees may impair auditor independence in the long run. The result is consistent with the works of O"Sullivan (1999) and Mitra et al. (2007) in terms of finding a positive relationship between the proportion of non-executive directors and auditors fees and they also reported statistically insignificant positive relationships. Carcello et al. (2000) also found a positive relationship between board characteristics and higher audit fees.

The size of the firm (SIZE) showed a co-efficient value of 0.9889 , a t- statistic of 2.3624 and a p-value of 0.0187 which indicate a statistical significance at the 5\% level. The most consistent result in all of the previous studies has been that company size is by far the most significant explanatory variable in determining audit fees. These results indicate that it costs more to audit larger clients than smaller ones, just as it may cost more to provide non-audit services to larger firms (clients) compared to smaller clients, where size is measured with respect to the logarithm of total assets. It is probable that audit work will increase with company size and, consequently, it is expected that bigger clients will pay higher audit fees than smaller clients (Whisenant et al., 2003). In other words, the bigger the client, all things being equal, the higher the total fees earned from such a client. These results are similar to the findings documented by other studies including Mitra et al. (2007), O'Sullivan (1999), Collier and Gregory (1999). Goddard and Masters (2000), O'Sullivan (1999) and Collier and Gregory (1999) are all UK studies and they all reported a significant positive relationship between measures of firm size, and auditor independence (fee) paid to the external auditors. They explained that these factors continue to be the major determinants of external auditors' fees. The result implies that $1 \%$ increase in the size of the firm will lead to $98 \%$ increase in audit fees. This result also implies that auditor independence is being affected negatively, especially in Nigeria with series of firms' collapse. This finding is consistent with the work of De Fuentes and Pucheta-Martínez (2009).

The result revealed that the big four (BIGF) is negatively associated with auditor independence. The coefficient of BIGF is -0.8237 with t-statistics of -1.9809 and significant at $5 \%$. Meanwhile, previous studies showed that auditor size (Cameran, 2005; Palmrose, 1986) is one of the variables that explain the level of audit fees. According to Chan et al. (1993) and Pong and Whittington (1994), this is because the large accounting firms spend a lot of time and effort on testing and analysing information and data. In addition, according to DeAngelo (1981), big accounting firms can charge premium being high quality auditors. Thus, a positive coefficient sign is expected on the BIG4 variable. However, the result of this study contradicted the proposition. It implied that in Nigeria, big companies audited by a big auditing firm had low levels of profit and this is justified by the negative coefficient of profitability in the model.

The result for Auditors' tenure (AUDTEN) has a negative significant relationship with audit fees, which in turn improve auditors' independence in Nigeria. However, a prolonged audit firm tenure may have a negative effect on the independence of an auditor even though we know that the attachment between directors and auditors is as a result of a continued business relationship. According to Antle et al. (2006), where auditors can charge higher 
audit fees in the first year of the audit engagement, a positive relationship can be expected between audit fees and auditor's tenure. This finding contradicts the result of Amake and Okafor (2012).

Table 5. Estimation results of the dynamic GMM model for the factors influencing auditor independence in Nigeria

\begin{tabular}{|c|c|c|c|c|}
\hline Variable & Coefficient & Std. Error & t-Statistic & Prob. \\
\hline LAUDIND(-1) & -0.0922 & 0.0579 & -1.5913 & 0.1124 \\
\hline BSIZE & 0.0517 & 0.084045 & 0.615089 & 0.5389 \\
\hline SIZE & $0.9889 * *$ & 0.4186 & 2.3624 & 0.0187 \\
\hline BIGF & $-0.8237 * *$ & 0.4158 & -1.9809 & 0.0483 \\
\hline AUDTEN & $-0.1401 *$ & 0.0784 & -1.7897 & 0.0743 \\
\hline LOSS & $0.5859 * *$ & 0.2391 & 2.4501 & 0.0147 \\
\hline OPINQUAL & 0.0371 & 0.6861 & 0.0540 & 0.9570 \\
\hline PROF & $-0.0005^{* *}$ & 0.00023 & -2.2560 & 0.0246 \\
\hline LEV & -0.7209 & 0.4835 & -1.4909 & 0.1368 \\
\hline INVREC & $-0.0022 * *$ & 0.00102 & -2.1006 & 0.0363 \\
\hline SUBLO & 1.3624 & 1.0663 & 1.2777 & 0.2021 \\
\hline SUBSFOR & 2.1223 & 2.3976 & 0.8852 & 0.3766 \\
\hline \multicolumn{5}{|c|}{ Effects Specification } \\
\hline \multicolumn{5}{|c|}{ Cross-section fixed (first differences) } \\
\hline Mean dependent var & 0.1337 & S.D. dependent var & & 0.4531 \\
\hline S.E. of regression & 0.7813 & Sum squared resid & & 228.9354 \\
\hline J-statistic & 10.5659 & Instrument rank & & 27 \\
\hline $\operatorname{Prob}(J$-statistic) & 0.782712 & & & \\
\hline Test order & m-Statistic & rho & SE(rho) & Prob. \\
\hline $\mathrm{AR}(1)$ & -2.9373 & -26.4301 & 8.9982 & 0.0033 \\
\hline $\mathrm{AR}(2)$ & -0.4660 & -4.9344 & 10.5885 & 0.6412 \\
\hline
\end{tabular}

$* * *, * *, *$ means significant at $1 \%, 5 \%$ and $10 \%$ respectively.

Source: Author's Computation 2015.

In order to capture audit risk (like, Chan et al., 1993), LOSS as a variable was included to reflect whether the company reported negative net income in the current year or in the two prior years (LOSS). Loss is significant at $5 \%$ with a coefficient of 0.5859 . This implies that the higher the loss, the higher the risk and the higher the audit fees which in turn influences auditor independence. Another variable in the auditor independence model to control for audit risk is whether the firms received a qualified audit report (OPINQUAL). Qualified audit report (OPINQUAL) had positive impact (0.0371) on auditor independence but not significant. Given that a qualified audit report is a measure of risk, a positive relationship between audit fees and a qualified opinion is expected. However, the relationship impairs on auditor independence negatively.

The result showed a statistically significant negative relationship between firms' profitability (PROF) and auditor independence. Profit after tax on total assets was used to proxy for profitability. The result produced a co-efficient value of -0.0005 and a t-statistic of -2.2560 , indicating significance at the $5 \%$ level. A negative relationship between a measure of profitability and auditor independence is explainable from the perspective of auditors' exposure to audit risk. Organisations that are making loss have a potential danger of going concern and may require more audit efforts in order to minimise audit risk and this may consequently lead to more fees being paid by such companies. As the profit is increasing audit fees reduces and thereby auditor independence is enhanced.

Leverage (LEV) is included to control for agency cost. Leverage is found to be insignificant and negatively related to auditor independence with a coefficient of -0.7209 . This implies that audit fees will reduce and auditor independence will be enhanced in the long run. A high ratio of inventory plus accounts receivable divided by total assets (INVREC) shows that the company has high levels of accounts receivable and inventory and, as a result, a greater audit effort will be required. However, INVREC had significant negative relationship with auditor independence with coefficient of -0.0022 and significant at 5\% level. It implies a reduction in audit fees and an increase in auditor independence.

The inclusion of the square root of the number of subsidiaries (SUBS) as well as the total number of subsidiaries 
(SUBSFOR) in the model was with a view to controlling for audit effort and complexity. The square root of the number of subsidiaries (SUBS) was positively related to auditor independence with a coefficient of 1.3624 , but not significant. Also, the total number of subsidiaries (SUBSFOR) had positive but insignificant influence on auditor independence. These results imply that the two variables may increase the complexity of the audit and, consequently, a rise or increase in audit fees in their presence and further reduction in auditor independence.

\section{Conclusion}

This study examined the factors influencing auditor independence among 65 listed companies in Nigeria. The study sought to establish the substantial proof of the identifiable factors by adopting a more reliable instrument which corrects the deficiencies observed in previous studies. Most of the existing studies in Nigeria focused on non-financial firms but this study provided evidence on the factors influencing auditor independence both in the financial and non-financial listed companies in Nigeria with the use of Generalised Method of Moments for the analysis of data in order to correct the deficiencies of Ordinary Least Square which was adopted by most previous studies. The findings of the study would enable management, regulators, investors and other stock market participants to play their unique and important roles in enhancing auditor independence in Nigeria.

The study revealed that Big4, audit tenure, profitability, leverage and inventory with account receivable had negative significant impact, which can impair auditor independence, while size of the firms and loss had positive influence on auditor independence in Nigeria. Also, the square root of the number of subsidiaries (SUBS) was positively related to auditor independence, but not significant and the total number of subsidiaries (SUBSFOR) had positive influence on auditor independence but not significant. These results implied that the two variables can increase the complexity of the audit and, consequently, a rise in audit fees expect in their presence. This will in turn reduce auditor independence. The study therefore recommended that joint audit be adopted and audited tenure be reviewed.

The study therefore recommended that joint audit be adopted and audit tenure be reviewed. It also recommended that, the Institute of Chartered Accountants of Nigeria (ICAN) and the Association of National Accountants of Nigeria (ANAN) should ensure that their professional members carry out their audit engagement with due diligence. Moreover, management, regulators, investors and other stock market participants should play their unique and important roles in enhancing auditor independence in Nigeria.

\section{References}

Abu Bakar, N. B., Abdul Rahman, A. R., \& Abdul Rashid, H. M. (2005). Factors Influencing Auditor Independence: Malaysian Loan Officers' Perceptions. Managerial Auditing Journal, 20(8), 804-822. https://doi.org/10.1108/02686900510619665

Adelopo, I., \& Jallow, K. (2008) Board Structures, Audit Committee Characteristics and External Auditors' Fee Behaviour. 2nd European Risk Conference, Universita Bocconi, Milan, Italy.

Adeyemi, S. B., \& Olowookere, J. K. (2012). Non-Audit Services and Auditor Independence Investors' Perspective in Nigeria. Business and Management Review, 2(5), 89-97.

Akinjobi, A., \& Omowumi, O. (2010). The Changing Responsibilities of Auditors in Detection and Prevention of Business Frauds within a Challenging Environment in Nigeria. Journal of Emerging Trends in Economics and Management Sciences 1(2), 71-75.

Alam, P., \& Baez-Díaz, A. (2005). The Joint Provision of Audit and Non-Audit Services: Evidence from the U.S. Banking. An International Meeting of the American Accounting Association, August 7-10, San Francisco, California.

Amake, C. O., \& Okafor, C. (2012). Auditors Independence, Auditors' Tenure and Audit Firm Size in Nigeria. Research Journal of Finance and Accounting, 3(10), 137-142

Antle, R., Gordon, E. A., Narayanamoorthy, G., \& Zhou, L. (2006). The Joint Determination of Audit Fees, Non-audit Fees and Abnormal Accruals. Review of Quantitative Finance and Accounting, 27(3), 235. https://doi.org/10.1007/s11156-006-9430-y

Arellano, M., \& Bond, S. (1991). Some Tests of Specification for Panel Data: Monte Carlo Evidence and an Application to Employment Equations. Review of Economic Studies, 58, 277-297. https://doi.org/10.2307/2297968

Arnold, B., \& Paul de Lange, P. (2004). Enron: An Examination of Agency Problems. Critical Perspectives on Accounting 15, 751-765. https://doi.org/10.1016/j.cpa.2003.08.005 
Beattie, V., \& Fearnley, S. (2003). Auditor Independence and Non-Audit Services: A Literature Review.

Beattie, V., Brandt, R., \& Fearnley, S. (1999). Perception of Auditor Independence: U.K. Evidence. Journal of $\begin{array}{llll}\text { International Accounting, Auditing and } & \text { 67-107. }\end{array}$ https://doi.org/10.1016/S1061-9518(99)00005-1

Bryman, A., \& Cramer, D. (1997). Quantitative Data Analysis with SPSS for Windows: A Guide for Social Scientists. London: Routledge.

Butterworth, S., \& Houghton, K. A. (1995). Auditor Switching: The Pricing of Audit Services. Journal of Business Finance and Accounting, 22(3), 323-344. https://doi.org/10.1111/j.1468-5957.1995.tb00877.x

Cameran, M. (2005). Audit Fees and the Large Auditor Premium in the Italian Market. International Journal of Auditing, 9, 129-146. https://doi.org/10.1111/j.1099-1123.2005.00205.x

Chan, P. M., Ezamel, M., \& Gwilliam, D. R. (1993). Determinants of Audit Fees for Quoted UK Companies. Journal of Business $\quad$ Finance $\&$ Accounting, 20(6), 765-786. https://doi.org/10.1111/j.1468-5957.1993.tb00292.x

Collier, P., \& Gregory, A. (1999). Audit Committee Activity and Agency Costs. Journal of Accounting \& Public Policy, 18, 311-32. https://doi.org/10.1016/S0278-4254(99)00015-0

Coulton, J., Craswell, A., \& Taylor, S. (2001). Do Board Characteristics Influence Audit Fees? Working Paper, University of Technology, Sydney and University of Sydney.

Craswell, A., Stokes, D., \& Laughton, J. (2002). Auditor Independence and Fee Dependence. Journal of Accounting and Economics, 14, 1-39. https://doi.org/10.1016/s0165-4101(02)00044-7

Craswell, T. S. L., \& Francis, J. R. (1995). Auditor Brand Name Reputations and Industry Specializations. Journal of Accounting \& Economic, 20(3), 297-305. https://doi.org/10.1016/0165-4101(95)00403-3

Dart, E. (2009). UK Investors' Perceptions of the Threats to Auditor Independence. University of Cardiff, Accounting and Finance Working Papers, A2009/1.

De Angelo, L. E. (1981). Auditor Independence, "Low Balling", and Disclosure Regulation. Journal of Accounting and Economics, 3(2), 113-127. https://doi.org/10.1016/0165-4101(81)90009-4

De Fuentes, B. C. (2005). Factores Determinants de la Evolucion Del Mercado de Auditoria en Espana. Doctoral Thesis, Department of Accounting, University of Valencia.

Deakin, S., \& Konzelmann, S. J. (2004). Learning from Enron. Corporate Governance: An International Review, 12(2), 134-142. https://doi.org/10.1111/j.1467-8683.2004.00352.x

Eisenhardt, K. M. (1989). Agency Theory: An Assessment and Review. Academy of Management Review, 14(1), 57-74.

Enofe, A. O., Nbgame, C. N., Okunega, E. C., \& Ediae, O. O. (2013). Audit Quality and Auditors Independence in Nigeria: An Empirical Evaluation. Research Journal of Finance and Accounting, 4(11), 131-138.

Ezzamel, M., Gwilliam, D. R., \& Holland, K. M. (1996). Some Empirical Evidence from Publicly Quoted UK Companies on the Relationship between the Pricing of Audit and Non-Audit Services. Accounting and Business Research, 27(1), 3-16. https://doi.org/10.1080/00014788.1996.9729528

Firth, M. (1997). The Provision of Non-Audit Services by Accounting Firms to their Audit clients. Contemporary Accounting Research, 14, 1-21. https://doi.org/10.1111/j.1911-3846.1997.tb00524.x

Firth, M. (2002). Auditor-Provided Consultancy Services and Their Associations with Audit Fees and Audit Opinions. Journal of Business Finance \& Accounting, 29(5\&6), 661-693. https://doi.org/10.1111/1468-5957.00446

Frankel, R. M., Johnson, M. F., \& Nelson, K. K. (2002). The Relation between Auditors' Fees for Non Audit Services and Earnings Management. The Accounting Review, 77, 71-105. https://doi.org/10.2308/accr.2002.77.s-1.71

Gallegos, F. (2004). Safeguarding Auditor Objectivity: Corporate Governance Practices must not Compromise Auditor Independence.

Gerrard, I., Houghton, K., \& Woodliff, D. (1994). Audit Fees: The Effects of Auditee, Auditor and Industry Differences. Managerial Auditing Journal, 9(7), 3-16. https://doi.org/10.1108/02686909410067534 
Hamid M. A., \& Abdullah A. (2011). Influence of Corporate Governance on Audit and Non-Audit Fees: Malaysian Evidence.

Hamid, K., \& Ali, Y. Q. (2012). Effective Factors on Determination of Audit Fees in Iran. Research Journal of Recent Sciences, 1(6), 38-44.

Hay, D., Knechel, R., \& Li, V. (2006). Non-Audit Services and Auditor Independence: New Zealand Evidence. Journal of Business Finance and Accounting, 33(5), 715-734. https://doi.org/10.1111/j.1468-5957.2006.00602.x

Hay, D., Knechel, R., \& Ling, H. (2008). Evidence on the Impact of Internal Control and Corporate Governance on Audit Fees. International Journal of Auditing, 12(1), 9-24. https://doi.org/10.1111/j.1099-1123.2008.00367.x

Hillison, W., \& Kennelley, M. (1988). The Economics of Non-Audit Services. Accounting Horizons, 2, 32-40.

Jensen, M. C., \& Meckling W. H. (1976). Theory of the Firm: Managerial Behaviour, Agency Costs and Ownership Structure. Journal of Financial Economics, 3(October), 305-60. https://doi.org/10.1016/0304-405X(76)90026-X

Lindberg, D. L., \& Beck. F. D. (2004). Before and after Enron: Certified Public Accountants' View on Auditor Independence. The CPA Journal Online, 97.

Low, L., Tan, P. H., \& Koh, H. (1990). Determination of Audit Fees: An Analysis in the Singapore Context. $\begin{array}{llll}\text { Journal of Business Finance and } & \text { Accounting, 17(2), }\end{array}$ https://doi.org/10.1111/j.1468-5957.1990.tb00561.x

Mautz, R. K., \& Sharaf, H. A. (1961). The Philosophy of Auditing. American Accounting Association, Sarasota, Florida.

Mitchell, A., \& Sikka, P. (2002). Dirty Business: The Unchecked Power of the Major Accounting Firms. A Monograph by the Association for Accountancy and Business Affairs, Basildon, UK.

Mitra, S., Hossain, M., \& Deis, D.R. (2007). The Empirical Relationship between Ownership Characteristics and Audit Fees. Rev Quant Finan Acc, 28, 257-285. https://doi.org/10.1007/s11156-006-0014-7

Moizer, P. (1997). Independence. In M. Sherer, \& S. Turley (Eds.), Current Issues in Auditing. Paul Chapman Publishing.

O"Sullivan, N., \& Diacon, S. R. (1996). The Impact of Organisational Form, Internal Governance and Non-Audit Services on Auditing Pricing. Working Paper, UK.

Okolie, A. O. (2014a). Auditor Tenure, Auditor Independence and Accrual - Based Earnings Management of Quoted Companies in Nigeria. European Journal of Accounting Auditing and Finance Research, 2(2), 63-90.

Okolie, A. O. (2014b). Audit Quality and Earnings Response Coefficients of Quoted Companies in Nigeria. Journal of Applied Finance \& Banking, 4(2), 139-161.

Okolie, A. O., Izedonmi, F. O. I., \& Enofe, A. O. (2013). Audit Quality and Accrual - Based Earnings Management of Quoted Companies in Nigeria. Journal of Economics and Finance, 2(2), 07-16. https://doi.org/10.9790/5933-0220716

Oladele, K. O. (2008). Auditor's Independence and Accountability in Nigeria Public Enterprises: A Case of the Nigerian Ports Authority. Retrieved from http://ssrn.com/abstract=1578182

Oladipupo, A. O., \& Izedonmi, F. I. O. (2011). Propensity of Unqualified Audit Reports and Auditors' Independence in Nigeria.

Palmrose, Z. (1988). An Analysis of Auditor Litigation and Audit Service Quality. The Accounting Review, 64(1), $55-73$.

Palmrose, Z. V. (1986). Audit Fees and Auditor size: Further Evidence. Journal of Accounting Research, 24(1), 97-110. https://doi.org/10.2307/2490806

Parkash, M., \& Venable, C. (1993). Auditee Incentives for Auditor Independence: The Case of Non-Audit Services. The Accounting Review, 68(1), 113-133.

Peel, M. J., \& Clatworthy, M. A. (2001). The Relationship between Corporate Governance Structure and Audit Fees Pre-Cadbury: Some Empirical Findings. Corporate Governance: An International Review, 9(4), 
286-297. https://doi.org/10.1111/1467-8683.00256

Pong, C. M., \& Whittington, G. (1994). The Determinants of Audit Fees: Some Empirical Models. Journal of Business Finance \& Accounting, 21(8), 1071-1095. https://doi.org/10.1111/j.1468-5957.1994.tb00365.x

Securities and Exchange Commission (SEC). (2000). Revision of the Commission's Auditor Independence Requirements (Releases No. 33-79919). SEC, Washington, DC.

Sharma, D. S. (2003). The Efficacy of Audit Committee Monitoring of Audit Quality: Tests of Main and Interaction Effects. Paper Presented at AFAANZ Conference, Brisbane, Australia.

Simunic, D. A. (1980). The Pricing of Auditing Services: Theory and Evidence. Journal of Accounting Research, 18(1), 161-190. https://doi.org/10.2307/2490397

Teoh, H. Y., \& Lim, C. C. (1996). An Empirical Study of the Effects of Audit Committees, Disclosure of Non-Audit Fees, and Other Issues on Audit Independence: Malaysian Evidence. Journal of International Accounting, Auditing \& Taxation, 5(2), 231-248. https://doi.org/10.1016/S1061-9518(96)90007-5

The Economist. (2002). Enron a Year on: Investor Self-Protection. November $30^{\text {th }}, 12$.

Vafeas, N., \& Waegelein, J. F. (2007). The Association between Audit Committees, Compensation Incentives, and Corporate Audit Fees. Rev Quant Finan Acc, 28(1), 241-255. https://doi.org/10.1007/s11156-006-0012-9

Whisenant, S., Sankaraguruswamy, S., \& Raghunandan, K. (2003). Evidence on the Joint Determination of Audit and Non-Audit Fees. Journal of Accounting Research, 41(4), 721-744. https://doi.org/10.1111/1475-679X.00121

Wooten, T. C. (2003). Research about Audit Quality. The CPA Journal, 73(1), 48-51.

\section{Copyrights}

Copyright for this article is retained by the author(s), with first publication rights granted to the journal.

This is an open-access article distributed under the terms and conditions of the Creative Commons Attribution license (http://creativecommons.org/licenses/by/4.0/). 